\title{
Fertility Suppression in Male Sprague-Dawley Rats by Administration of Methanolic Extract of Hempedu bumi (Andrographis paniculata) \\ (Penindasan Kesuburan dalam Tikus Jantan Sprague-Dawley melalui Pemberian Ekstrak Metanol Hempedu bumi (Andrographis paniculata))
}

\author{
DAYANG NURUL FATIHAH \& MAHANEM, M.N.*
}

\begin{abstract}
The recent expanding rat population is causing severe economic losses and diseases in human. The main objective of this study was to evaluate the antifertility effects of Andrographis paniculata (AP) methanol extract on the weight of testis, sexual behaviour, fertility, sperm quality and serum testosterone level in treated male rats compared with control rats. A total of 21 adult male rats Sprague-Dawley aged 12 weeks were divided into three groups; control group (distilled water), low dose group $(800 \mathrm{mg} / \mathrm{kg})$ and high dose group $(1600 \mathrm{mg} / \mathrm{kg})$ of AP methanol extracts given orally for 24 days. Body and testis weight, sexual behaviour test, fertility test, sperm quality and serum testosterone level were measured. Oral administration of AP methanol extract showed a significant decrease in testis weight, number of mountings, number of fetuses, sperm count, sperm motility and serum testosterone levels for all treatment group as compared with the control group, whereas mortality showed a significant increase. Observation on testis histology of treatment group exhibited features of degeneration in Sertoli cells and germinal cells in the seminiferous tubules, followed by the shrinkage of Leydig cells as compared with the control group, which showed characteristics of normal spermatogenesis. In conclusion, $\mathrm{AP}$ methanol extract exhibited antifertility effects in male rats, suggesting that $\mathrm{AP}$ is a potential herb to be applied as rodenticide.
\end{abstract}

Keywords: Andrographis paniculata; infertility; male contraception; sexual behaviour; sperm quality; testosterone

\section{ABSTRAK}

Peningkatan populasi tikus mendatangkan kerugian daripada segi ekonomi dan penyakit kepada manusia. Objektif utama kajian ini dijalankan adalah untuk menguji kesan ekstrak Andrographis paniculata (AP) ke atas berat testis, kelakuan seksual, kesuburan, kualiti sperma dan aras hormon testosteron tikus jantan perlakuan berbanding kawalan. Sebanyak 21 ekor tikus jantan dewasa Sprague-Dawley berusia 12 minggu dibahagikan kepada tiga kumpulan; kumpulan kawalan (air suling), dos rendah $(800 \mathrm{mg} / \mathrm{kg}$ ) dan dos tinggi (1600 mg/kg) ekstrak AP yang diberikan secara suap paksa selama 24 hari. Berat badan dan berat testis, kelakuan seksual, kesuburan, kualiti sperma dan aras hormon testosteron diukur dan dicatat. Pemberian ekstrak AP secara suap paksa menunjukkan penurunan yang signifikan pada berat testis, bilangan pemanjatan, jumlah fetus, bilangan sperma, motiliti sperma, aras hormon testosteron pada semua kumpulan tikus perlakuan berbanding kawalan, manakala gred mortaliti sperma menunjukkan peningkatan yang signifikan. Pemerhatian ke atas histologi testis tikus yang diberi perlakuan ekstrak AP mempamerkan ciri-ciri degenerasi pada sel germinal tubul seminiferus dan sel Sertoli, serta berlaku pengecutan pada sel Leydig, berbanding dengan kumpulan kawalan yang menunjukkan ciri-ciri spermatogenesis yang normal. Kesimpulannya, ekstrak AP didapati memberi kesan antikesuburan pada tikus jantan, seterusnya mencadangkan tumbuhan AP berpotensi untuk digunakan sebagai rodentisid.

Kata kunci: Agen kontraseptif; Andrographis paniculata; antikesuburan; kelakuan seksual; kualiti sperma; testosteron

\section{INTRODUCTION}

Expanding rat population is causing severe economic losses in Malaysian agriculture and severe diseases such as leptospirosis, typhus fever and rat-bite fever disease in human. In oil palm plantation, the crop losses caused by rats feeding on palm fruit have been estimated to be in the region of $5 \%$ of the oil yield and in severe cases, the losses can rise up between 7 and $10 \%$ of the total oil production, which is about $165 \mathrm{~kg}$ of oil per hectare per year (Matori 2009). According to Andreas et al. (2003) and the Government of South Australia (2008), over $31 \%$ of the reported cases, leptospirosis, typhus fever and rat-bite fever happen due to direct contact with rats. An article reported that rat population has the potential to increase 500 times each year due to the high reproductive rate of rats (Food and Fertilizer Technology Center 2002). The Subang Jaya Municipal Council (MPSJ) has declared war on rats by rewarding the public with RM1 for each rodent caught (The Star@online 2009). This problem caused the scientists all over the world to put much emphasis on herbs and plants in fertility control and as alternative means of pest control, which can minimize the use of chemical 
control method for managing the recently expanding rat population (Sakilah et al. 2009).

Currently, broad-scale chemical control is the primary method used for managing the expanding of rat population. However, it generally provides effective control only in a short-term due to the resistance toward chemical poison. The use of chemicals raises a number of concerns, such as the risk to non-target species and the humaneness of their action. The alternative to chemical control approach is to use herbs and plants that cause infertile as a biological control. Herbal drugs are usually effective, inexpensive and affordable by people of rural area (Matori 2009). According to the National Pesticide Information Center (2011), rodenticide is a pesticide that kills rodents such as rats, mice, squirrels, woodchucks, chipmunks, porcupines and beavers. Rodenticide can be grouped according to how they work. Rodenticides that are able to stop normal blood clotting are called anticoagulants. Bromadiolone, chlorophacinone, difethialone, brodifacoum and warfarin are all anticoagulants. Rodenticides that are not anticoagulants work differently. Zinc phosphide, bromethalin, cholecalciferol and strychnine are examples of non-anticoagulants. Antifertility plant extracts is the practice of a whole or a part of the plant that possess antifertility activity to control fertility such as antiimplantation, abortification, ecobolic, oestrogenic and spermidal (Saravanan et al. 2012).

Andrographis paniculata (AP) is a medicinal plant having antipyretic, antihepatotoxic, choleretic, anticancer, reducing hypertension, antidiabetics and immunostimulant anti-HIV properties and it is also effective in the treatment of common cold (Niranjan et al. 2010). Andrographolide is a major active component in the AP leaves (2.39\%). It has been shown to possess many pharmacological effects (Srisuwan et al. 2009). The analysis of extracts from diterpenoid lactones in AP leaves indicated a large yield of andrographolide when the extractions were carried out using a polar organic solvent containing a hydroxyl group, namely methanol (Kumoro et al. 2009). Several animal studies showed that AP may have anti-fertility effects on male and female rat's reproductive system. Zoha et al. (1989) evaluated the anti-fertility effect of AP in the screening programme with both male and female rats and confirmed the anti-fertility effect. In male rats, AP caused arrest in spermatogenesis, decreased sperm count and motility and several of them possessed abnormalities in sperm morphology (Akbarsha \& Muragaian 2000; Akbarsha et al. 1990). Sakilah et al. (2009) reported that AP caused infertility in female rats due to lower level of reproductive hormones such as $\mathrm{FSH}, \mathrm{LH}$, estrogen and progesterone. On the other hand, Burgos et al. (1997) reported that AP dried extracts demonstrated no subchronic testicular toxic effects and morphological or functional changes in Leydig cells. Moreover, Mkrtchyan et al. (2005) described no significant negative effect of AP on male semen quality and fertility could be observed and rather the comment by the principally of volunteers was feeling of enhanced sexual potency during masturbation.
Furthermore, Sattayasai et al. (2010) reported the aphrodisiac-like effect of AP is comparable to sildenafil. Since earlier studies reported the effects of AP on fertility either negative (Akbarsha \& Muragaian 2000; Akbarsha et al. 1990; Sakilah et al. 2009; Zoha et al. 1989), positive (Mkrtchyan et al.2005; Sattayasai et al.2010) or no effect (Burgos et al. 1997), therefore the present study was carried out to further clarify the effect of AP on male rat fertility.

\section{MATERIALS AND METHODS}

\section{PREPARATION OF A. PANICULATA METHANOL EXTRACT}

The plant material was collected from Universiti Putra Malaysia (UPM), Serdang. Only the leaves were used for the study because of high andrographolide content compared with other AP plant parts (Jarumkamjorn \& Nemoto 2008). AP leaves were dried and ground to coarse powder and extracted by using Soxhlet apparatus at $60^{\circ} \mathrm{C}$ with the presence of methanol. The AP methanol extract was then transferred to a rotary evaporator to obtain a concentrated extract. The yield of AP methanol extract was $9.64 \%$.

\section{ANIMALS}

The experiments were conducted using 21 Sprague-Dawley rats supplied by Animal House of Universiti Kebangsaan Malaysia (UKM), Bangi. All rats were clinically healthy. Water and food were given ad libitum. The animals were divided into three groups; control group (received distilled water), lower dosage group $(800 \mathrm{mg} / \mathrm{kg})$ and higher dosage group $(1600 \mathrm{mg} / \mathrm{kg})$. The dosage of extracts was suspended in $0.8 \mathrm{~mL}$ of distilled water, while the control group received an equal volume of distilled water. The treatment was administered orally using force feeding needles (Animal Feeding Needles by Popper \& Sons Inc.) for 14 days. The study was approved by the Animal Ethics Committee of Faculty of Medicine, Universiti Kebangsaan Malaysia (FST/2013/MAHANEM/31-JAN./492-FEB.2013-FEB.-2015).

\section{SEXUAL BEHAVIOUR TEST}

Sexual behaviour test was done to examine the effect of AP methanol extract in rats after the completion of 14 days of treatment. The test was performed according to the male rat sexual protocol as done by Agmo (1997). Before the test was carried out, healthy and naive female rats used in this study were artificially brought into estrous by subcutaneous injections of $\beta$-estradiol-3-benzoate $(20 \mu \mathrm{g} / \mathrm{rat})$ and progesterone in $(1 \mu \mathrm{g} / \mathrm{rat}) 52$ and $4 \mathrm{~h}$, respectively, prior to experiment. The animals were adapted to laboratory conditions for $10 \mathrm{~min}$ before the test. A male rat was placed in the test cage and 5 min later, a female rat was inserted into the cage and the number of false mountings was recorded. The observation period was $5 \mathrm{~min}$. Sexual behavior was determined by mounting frequency (number of mounts). 


\section{FERTILITY TEST}

Fertility test was done to study the effect of AP on mating outcome and fertility (pregnancy) of the treated group compared with the control group. After two weeks of completion of force feeding with AP, each male rat was kept in a different cage together with two estrous female rats to mate for five days. Vaginal smears were performed to determine the first day of gestation. Pregnant female rats were then separated and kept for 16 days before sacrificed and the number of fetuses in the uteri was recorded (Chauhan \& Agarwal 2009).

\section{SPERM QUALITY ANALYSIS (SPERM COUNT, MOTILITY AND MORTALITY)}

On day 25, the control and treated groups were sacrificed under chloroform anaesthesia and dissected to obtain cauda epididymis. The cauda epididymis was minced in $10 \mathrm{~mL}$ of Biggers, Whitten \& Whittingham (BWW) medium in a petri dish prior to incubation in $5 \% \mathrm{CO}_{2}$ incubator at $37^{\circ} \mathrm{C}$ for $30 \mathrm{~min}$ to allow the migration of spermatozoa (Biggers et al. 1971). Sperm qualities were determined according to the method prescribed by the World Health Organization (WHO 1999) using improved Neubauer haemocytometer.

\section{SERUM TESTOSTERONE LEVEL}

Blood samples were collected directly from all groups by cardiac puncture for estimation of serum testosterone level using a commercial kit. All samples were assessed as per manufacturer's manual (Testosterone EIA Kit by Cayman Chemical Company).

\section{HISTOLOGY OF TESTIS}

Histological examination of the testis was based on the method described previously (Humason 1979). One (left) of the two testes of each animal was fixed in Bouin's fixative solution for $24 \mathrm{~h}$. All samples were then dehydrated in graded ethanol series, cleared in toluene and embedded in paraffin. Tissues were sectioned at $6 \mu \mathrm{m}$ thickness and stained with hematoxylin and eosin (H\&E). The slides were evaluated under light microscope. Testicular spermatogenesis ranging from germ cell production up to the stage of mature spermatozoa was evaluated.

\section{STATISTICAL ANALYSIS}

The data were expressed as mean \pm SEM. The statistical analysis performed used one-way analysis of variance
(ANOVA), followed by the Tukey test to compare the mean parameters studied with values $p<0.05$ was considered a statistically significant difference.

\section{RESULTS}

The oral administration of AP methanol extracts (800 and $1600 \mathrm{mg} / \mathrm{kg}$ body weight/day) for 24 consecutive days did not cause any significant change in body weight of the treated and control rats (Figure 1). However, the result of testis weight showed a significant reduction $(p<0.005)$ compared with the control group (Table 1).

A significant decrease was observed in mounting frequency $(p<0.005)$ of the treated groups compared with the control group. However, there was no significant difference in the frequency of mountings for $800 \mathrm{mg} / \mathrm{kg}$ and $1600 \mathrm{mg} / \mathrm{kg}$ AP methanol extracts (Table 1).

The results from the fertility test showed a dosedependent reduction in the treated groups. Table 2 shows the percentage of infertile male rats in lower and higher dosage groups, respectively, which were 40 and $80 \%$ of the control following 14 days of treatment. The number of fetuses declined to $4.60 \pm 2.11$ and $1.40 \pm 1.40$, respectively, compared with $11.00 \pm 1.70$ in the control group (Table 2). The higher dosage group showed a significant reduction $(p<0.005)$ in the number of fetuses compared with control

The AP methanol extract treated rats in Table 3 showed a significant reduction $(p<0.005)$ in the cauda epididymal sperm count compared with control. The sperm motility grade was also reduced from grade $b$ in the control group to grade $\mathrm{d}$ in the treated groups. The treated groups showed a significant increased of sperm mortality $(p<0.005)$ compared with control.

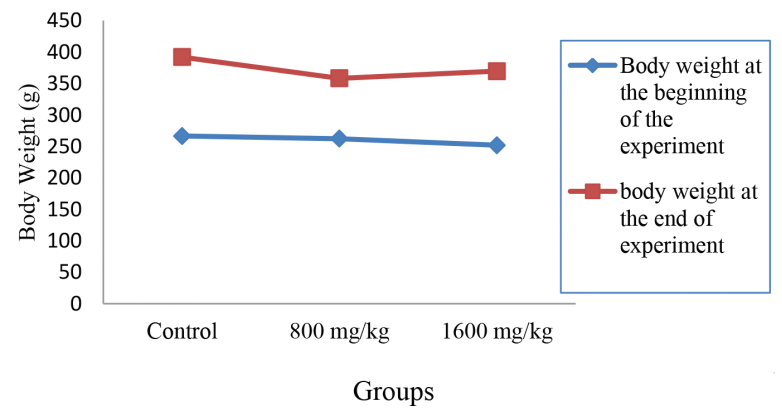

FIGURE 1. Effects of AP methanol extract on mean body weight $(\mathrm{g})$ of male rats at the beginning and the end of experiment

TABLE 1. Effects of AP methanol extract on testis weight $(\mathrm{g})$ and mounting frequency. Values are mean \pm SEM

\begin{tabular}{ccc}
\hline Groups $(\mathrm{mg} / \mathrm{kg})$ & Testis $(\mathrm{g})$ & Mounting frequency $(5 \mathrm{~min})$ \\
\hline Control & $1.44 \pm 0.02$ & $2.80 \pm 0.58$ \\
800 & $1.26 \pm 0.04^{*}$ & $0.80 \pm 0.58^{*}$ \\
1600 & $1.24 \pm 0.02^{*}$ & $0.40 \pm 0.40^{*}$ \\
\hline
\end{tabular}

*Significantly different compared with control $(p<0.005)$ 
TABLE 2. Effects of AP methanol extract on number of fetuses and percentage of infertile male rats. Values are mean \pm SEM

\begin{tabular}{ccc}
\hline Groups $(\mathrm{mg} / \mathrm{kg})$ & Number of fetuses & Infertile male rats $(\%)$ \\
\hline Control & $11.00 \pm 1.70$ & 0 \\
800 & $4.60 \pm 2.11$ & 40 \\
1600 & $1.40 \pm 0.40^{*}$ & 80 \\
\hline
\end{tabular}

*Significantly different compared with control $(p<0.005)$

TABLE 3. Sperm count $\left(\times 10^{6}\right)$, motility grade and mortality of treated and control groups

\begin{tabular}{cccc}
\hline Groups $(\mathrm{mg} / \mathrm{kg})$ & Sperm count $\left(\times 10^{6}\right)$ & Motility grade $(\mathrm{a}-\mathrm{d})$ & Sperm mortality $\%$ \\
\hline Control & $33.09 \pm 4.93$ & $\mathrm{~b}$ & $13.63 \pm 1.57$ \\
800 & $18.07 \pm 2.32^{*}$ & $\mathrm{~d}$ & $50.58 \pm 8.69^{*}$ \\
1600 & $16.25 \pm 2.61^{*}$ & $\mathrm{~d}$ & $51.52 \pm 8.68^{*}$ \\
\hline
\end{tabular}

*Significantly different compared with control $(p<0.005)$

Motility grade according to WHO manual (1999).

a: rapid progressive motility; $\geq 25 \mu \mathrm{m} / \mathrm{s}$ at $37^{\circ} \mathrm{C}$ and $\geq 20 \mu \mathrm{m} / \mathrm{s}$ at $20^{\circ} \mathrm{C}$

b: slow or sluggish progressive motility

c: non-progressive motility; $<5 \mu \mathrm{m} / \mathrm{s}$

d: immotility

Serum testosterone levels are shown in Figure 2. In treated rats, testosterone level decreased significantly $(p<0.005)$ when compared with control in a dosedependent manner. The normal serum testosterone levels of Sprague-Dawley rats are $0.84 \pm 0.07 \mathrm{ng} / \mathrm{mL}$ (Turk et al. 2007). These findings underlined the anti-fertility activity of AP on male rat's reproductive system.

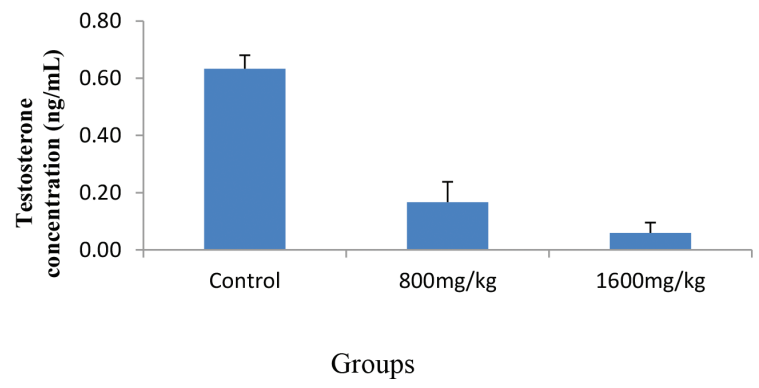

FIGURE 2. Effects of AP methanol extract on serum testosterone level of control and treated groups. Data are expressed as mean $\pm \mathrm{SEM}$

Histological studies of control rat testis showed normal appearance of seminiferous tubules with all successive stages of spermatogenesis, where the lumen was filled with spermatozoa. Normal intertubular spaces with connective tissue were observed (Figure 3). For the lower dosage group (Figure 4), the section of testis showed degeneration of spermatogenic elements with the appearance of vacuoles. The lumen was partially filled with spermatozoa. Loosened intertubular spaces increased and shrinkage of Leydig cells was also observed. For rats treated with $1600 \mathrm{mg} / \mathrm{kg}$ of AP (Figure 5), the degeneration of spermatogenic elements and the appearance of vacuoles were more pronounced in the higher dose treated rats than in the lower dose treated rats. Very few spermatozoa were seen in the lumen.

\section{DISCUSSION}

The results of this study demonstrated that daily consumption of AP methanol extract for 24 consecutive days did not affect body weight. These findings are in accordance with the investigation of Akbarsha and Muragaian (2000), who found no change in body weight of the rats treated with andrographolide. The safety effects of AP on rat's body weight, growth, appetite, liver and kidney function have been reported and none of them died during the treatment (Niranjan et al. 2010).

However, a significant reduction in testicular weight of the treated group can be attributed to the loss of germ cells known to be mostly related to the number of spermatids and spermatozoa present in the testes and decreased the production of seminiferous tubular fluid (Gupta et al. 2007). Akbarsha et al. (1990) described that administration of dry leaf powder of AP to male rats resulted in a decrease of reproductive organ weight by affecting both spermatogenesis and Leydig cells.

A significant decrease in the mounting frequency observed in the treated groups suggested that the extract affects male sexual behavior due to the effect of the extract on testosterone production and the sensitivity of the target organs to the hormone. This belief is further supported by the results of sperm quality analysis and serum testosterone level. According to Gupta et al. (2013), male sexual behaviour is influenced by testosterone levels.

The result from the fertility test showed that treated male rats groups reduce the number of fetuses compared with the control group. The high dose of $1600 \mathrm{mg} / \mathrm{kg}$ 


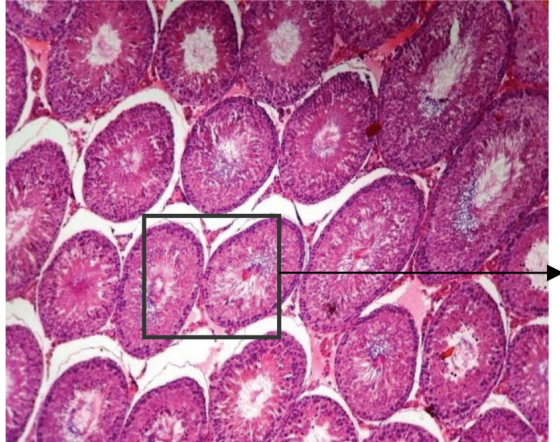

(a)

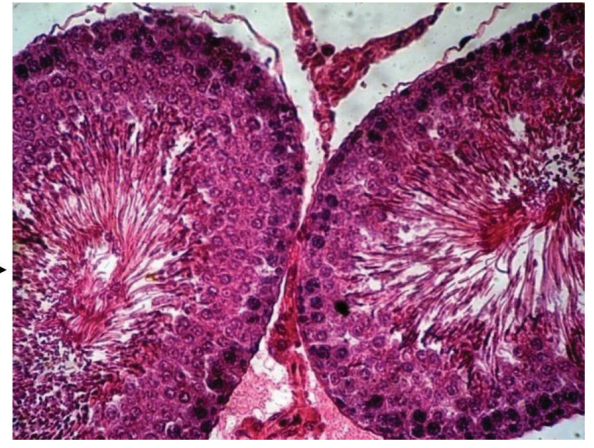

(b)

FIGURE 3. Photomicrograph of rat testis in the control group showing normal features with successive stages of spermatogenesis and normal intertubular spaces with connective tissues. Lumen of seminiferous tubules was filled with spermatozoa (a) $\times 100$ and (b) $\times 400$

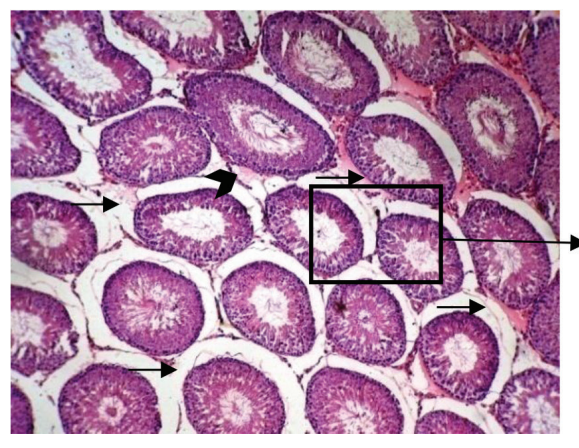

(a)

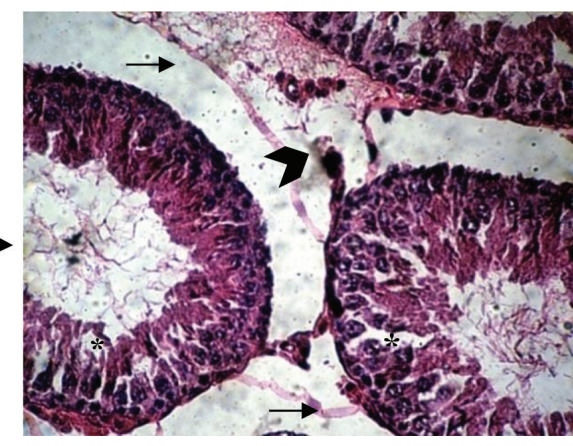

(b)

FIGURE 4. Photomicrograph of rat testis in the low dose group $(800 \mathrm{mg} / \mathrm{kg}$ ) showing degeneration of spermatogenic elements with appearance of vacuoles (asterix). Loosened intertubular spaces increased (arrows). Seminiferous tubule showed shrinkage of Leydig cells (arrow head) (a) $\times 100$ and (b) $\times 400$

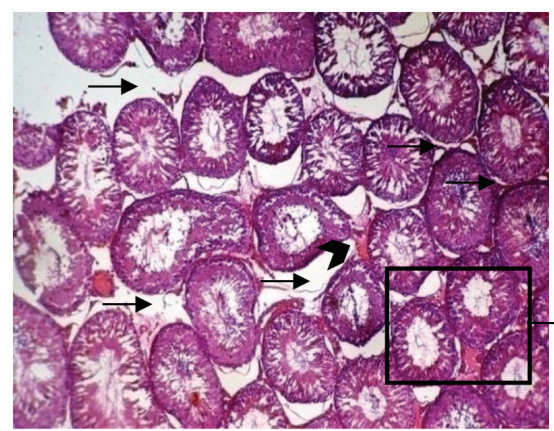

(a)

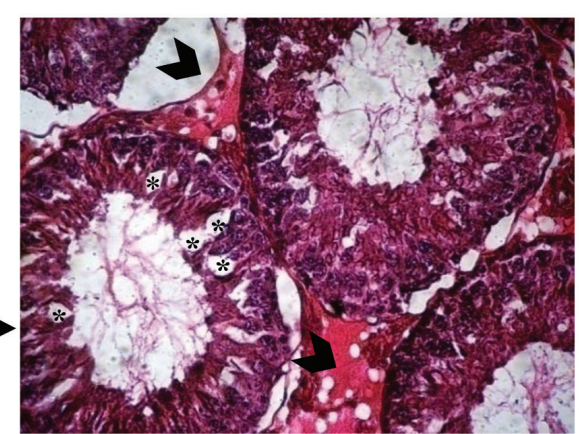

(b)

FIGURE 5. Photomicrograph of rat testis in the high dose group $(1600 \mathrm{mg} / \mathrm{kg})$ exhibiting severely degeneration

of spermatogenic elements with appearance of vacuoles (asterix). Disorganised seminiferous tubules orientation (arrows). Seminiferous tubule showed the rarity of Leydig cells (arrow head) (a) $\times 100$ (b) $\times 400$

showed a significant reduction in the number of fetuses $(p<0.005)$ and $50 \%$ reduction in sperm count compared with control. The reduction in the number of fetuses after administration of AP extract observed in this study could be due to the markedly reduced sperm count and motility. Inadequate concentration and immotile sperm could not penetrate the cervical mucus and thus failed to fertilize the ova (Gupta et al. 2006).

In the current study, treatment with AP extract caused a significant reduction in sperm count and motility and increase in sperm mortality suggested spermatotoxic effect of AP methanol extract (Akbarsha \& Muragaian 2000). In 
addition, AP and andrographolide had a negative effect on spermatogenesis in rats by preventing cytokinesis of the dividing spermatogenic cell lines with appearances of damaged Sertoli cells and a spermatotoxic effect (Jarukamjorn \& Nemoto 2008).

Reproductive organ morphology and physiology are maintained by testosterone hormone, but the threshold levels of required hormone might be different for different functions. Reduction of testosterone level in the treated group might have effects on spermatogenesis, cellular structures and other male reproductive functions such as the inhibition of gonadotropin-releasing hormone, luteinizing hormone secretion, induction and maintenance of differentiation of male accessory reproductive organs and hence, reduction in sperm count (Bajaj \& Gupta 2011; Shkukani et al. 2007). Studies on other plant, for example Centella asiatica $\mathrm{L}$. extract as male antispermatogenic and antifertility agents, demonstrated that the decrease in the level of serum testosterone resulting in the decrease of sperm quality (Yunianto et al. 2010).

A negative impact of AP methanol extract on the structural and functional integrity of the testicular tissues is shown by the histological analysis, highlighting the degeneration of spermatogenic elements with the appearance of vacuoles. All treated groups showed abnormal features of seminiferous tubules and Leydig cells. These results showed that the negative effect of AP methanol extract on spermatogenesis was more pronounced in the higher dose treated rats $(1600 \mathrm{mg} / \mathrm{kg})$. These findings were in line with the earlier report of Akbarsha and Muragaian (2000) and Akbarsha et al. (1990) that Andrographis paniculata resulted in degenerative changes of seminiferous tubules and decreased spermatogenesis.

The observed rarity on Leydig cells of treated rats (Figures 4 and 5) probably correspond to the significant decrease in testosterone production (Figure 2); hence disrupts spermatogenesis. Leydig cells influence the seminiferous tubules by maintaining a high concentration of testosterone in the peritubular compartments of the testis. The Leydig cells produce male hormone testosterone, which is important for spermatogenesis, sexual differentiation during embryonic and fetal development and control of gonadotropin secretion (Fox 2006). These findings are similar to published reports that Mucuna urens (Etta et al. 2009) caused degeneration of Leydig cells, thus causing an arrest of spermatogenesis, reduction in sperm count and hence decrease in fertility, which was further evidenced by the reduction in litter size.

The presence of vacuoles was more pronounced at higher dose $(1600 \mathrm{mg} / \mathrm{kg})$ than at lower dose $(800 \mathrm{mg} / \mathrm{kg})$ body weight of AP treated rats. According to Akbarsha and Murugaian (2000), Revathi et al. (2010) and Stephen and Yinusa (2011), vacuolization at the epithelium of seminiferous tubules indicates death or exfoliation of spermatogenic cell. Henics and Wheatley (1999) explained that the process of cytoplasmic vacuolation primarily reflects an adaptive, survival response to a plethora of environmental changes, which also have the potential to lead to a particular and distinctive form of cell death. Vacuolization of the seminiferous tubules might imply that AP extract was able to permeate the blood-testis barrier and caused arrest of spermatogenesis (Stephen \& Yinusa 2011).

Sertoli cells are the somatic cells of the testis that are essential for spermatogenesis as the cells facilitate the differentiation of primordial germ cells to spermatogonia. The results from the histology of testis showed a reduction in the number of Sertoli cells with appearances of vacuoles as AP extract would definitely expose the germ cells and the developing spermatocytes within the seminiferous tubules of the testis to the toxic effects of AP. Sertoli cells also constitute to the blood-testis barrier, thus damage to Sertoli cells may lead to impairment of male reproduction. Hence, the degeneration of seminiferous tubule and Sertoli cells supported the antispermatogenic effects of AP extracts on male rats (Bajaj \& Gupta 2011).

Although the mechanism in which Andrographis paniculata exerted its antispermatogenic and antifertility effects are still debatable, it has been suggested that the species possesses the ability to disrupt spermatogenesis by acting on both Leydig and Sertoli cells as shown by the rarity of Leydig cells and degeneration of germinal epithelium in AP treated rats.

In conclusion, the results of this study provide evidence that AP methanol extract has the potential to be used as a plant-based contraceptive method for male rats and as a biological control agent for managing rodent pest problem. Further studies are warranted to study the reversible anti-fertility effect of AP and its mechanism of action.

\section{ACKNOWLEDGEMENTS}

This study was supported by the World Federation of Scientists (WFS) National Scholarship Programme Switzerland and Faculty of Science and Technology, Universiti Kebangsaan Malaysia (UKM).

\section{REFERENCES}

Agmo, A. 1997. Protocol male rat sexual behavior. Brain Research Protocols 1: 203-209.

Akbarsha, M.A., Manivannan, B., Hamid, K.S. \& Vijayan, B. 1990. Antifertility effect of Andrographis paniculata (Nees) in male albino rat. Indian Journal of Experimental Biology 28: 421-426.

Akbarsha, M.A. \& Murugaian, P. 2000. Aspects of the male reproductive toxicity/male antifertility property of Andrographolide in albino rats: Effect on the testis and the cauda epididymidal spermatozoa. Phytotherapy Research 14: 432-435.

Andreas, J., Irene, S., Christina, F., Kathrina, A., Thomas, S. \& Klaus, S. 2003. Leptospirosis in Germany - 1962-2003. Emerging Infectious Diseases 11(7): 1048-1054.

Bajaj, V.K. \& Gupta, R.S. 2011. Fertility suppression in male albino rats by administration of methanolic extract of Opuntia dillenii. Andrologia 44: 530-537. 
Biggers, J.D., Whitten, W.K. \& Whittingham, D.G. 1971. The culture of mouse embryos in vitro. In Methods in Mammalian Embryology, edited by Daniel, J.C. San Francisco: Freeman. pp 86-116.

Burgos, R.A., Caballero, E.E., Sanchez, N.S., Schroeder, R.A., Wikman, G.K. \& Hancke, J.L. 1997. Testicular toxicity assessment of Andrographis paniculata dried extract in rats. Journal of Ethnopharmacology 58: 219-224.

Chauhan,A.\& Agarwal,M.2009. Assessment of the contraceptive efficacy of the aqueous extract of Aegle marmelos Corr. leaves in the male albino rats. Human fertility 12: 107-118.

Etta, H.E., Bassey, U.P., Eneobong, E.E. \& Okon, O.B. 2009. Anti-spermatogenic effects of ethanol extract of Mucuna pruriens. Journal of Reproduction \& Contraception 20(3): 161-168.

Food and Fertilizer Technology Center. 2002. Barn Owls to Control Rats in Paddy Fields. http://www.agnet.org/library/ pt/2002005. Accessed on 15 May 2011.

Fox, S.I. 2006. Human Physiology. New York: McGraw Hill.

Government of South Australia. 2008. Rats: Prevention and Control.http://dh.sa.gov.au/pehs/PDF-files/ph-factsheet-rats. pdf . Accessed on 28 January 2010.

Gupta, A.K., Bindal, M.C., Gupta, S.K., Prakash, D. \& Vedpal. 2013. Aphrodisiac activity of Semecarpus anacardium nut. International Research Journal of Pharmacy 4(4): 202-204.

Gupta, R.S., Kachhawa, J.B.S. \& Sharma, A. 2007. Effect of methanolic extract of Dendropthoe falcate stem on reproductive function of male albino rats. Journal of Herbal Pharmacotherapy 7(2): 1-13.

Gupta, R.S., Kachhawa, J.B.S., Khushalani, V., Tanwar, K. \& Joshi, Y.C. 2006. Effect of Cressa cretica methanol extract on testicular function of albino rats. Pharmaceutical Biology 44: 382-388.

Henics, T. \& Wheatley, D.N. 1999. Cytoplasmic vacuolation, adaptation and cell death: A view on new perspectives and features. Biology of the Cell 91: 485-498.

Humason, G.L. 1979. Animal Tissue Techniques. San Francisco: Freeman.

Jarumkamjorn, K. \& Nemoto, N. 2008. Pharmacological aspects of Andrographis paniculata on health and its major diterpenoid constituent andrographolide. Journal of Health Science 54: 370-381.

Kumoro, A.C., Hasan, M. \& Singh, H. 2009. Effects of solvent properties on the Soxhlet extraction of diterpenoid lactones from Andrographis paniculata leaves. Science Asia 35: 306-309.

Matori, M.H. 2009. Pengawalan perosak tikus di ladang sawit. Suara Risda.p. 4.

Mkrtchyan, A., Panosyan, V., Panossian, A., Wikman, G. \& Wagner, H. 2005. A phase 1 clinical study of Andrographis paniculata fixed combination Kan Jang versus ginseng and valerian on the semen quality of healthy male subjects. Phytomedicine 12: 403-409.

National Pesticide Information Center. 2011. Rodenticides topic fact sheet. http://npic.orst.edu/factsheets/rodenticides.html. Accessed on 28 February 2015.

Niranjan, A., Srisuwan, S., Tewari, S.K. \& Lehri, 2010. A. biological activities of Kalmegh (Andrographis paniculata Nees) and its active principles-A review. Indian Journal of Natural Products and Resources 1: 125-135.
Revathi, P., Vani, B., Sarathchandiran, I., Kadalmani, B., Shyam, K.P. \& Palnivel, K. 2010. Reproductive toxicity of Capparis aphylla (Roth.) in male albino rats. International Journal of Pharmacology and Biomedicinal Research 1(3): 102-112.

Sakilah, S., Begum, N., Kawsar S., Begum, Z.A. \& Zola, M.S. 2009. Relationship of anti-fertility effects of Andrographis paniculata and hormonal assay in female rats. Bangladesh Journal of Medical Science 8(1-2): 10-14.

Saravanan, K., Priya, G. \& Renuka, C. 2012. Medicinal plants with potential antifertility activity- A review of sixteen years of herbal medicine research (1994-2010). International Journal of PharmTech Research 4(1): 481-494.

Sattayasai, J., Srisuwan, S., Arkaravichien, T. \& Aromdee, C. 2010. Effects of andrographolide on sexual functions, vascular reactivity and serum testosterone level in rodents. Food and Chemical Toxicology 48: 1934-1938.

Shkukani, H.G., Salhab, A.S., Disi, A.M., Shomaf, M.S. \& Quadan, F.A. 2007. Antifertility effect of ethanolic extract of Juniperus phoenica (L.) in male albino rats. Journal of Herbal Pharmacotherapy 7: 3-4.

Srisuwan, S., Sattayasain, J., Arkaravichien, T. \& Aromdee, C. 2009. Effects on andrographolide and its semisynthetic derivative on sexual behaviours in male mice. Thai Journal of Pharmacology 31: 68-71.

Stephen, A.O. \& Yinusa, R. 2011. Prolonged administration of proguanil induces reproductive toxicity in male rats. Journal of Toxicology Sciences 36: 587-99.

The Star Online. MPSJ Offers Bounty on Rats. 11 June 2009. http://www.thestar.com.my/story.aspxfile $=\% 2 \mathrm{f} 2009 \% 2 \mathrm{f} 6$ $\% 2 \mathrm{f} 22 \% 2 \mathrm{fcentral} \% 2 \mathrm{f} 4116329 \& \mathrm{sec}=$ central. Accessed on 8.1.2014.

Turk, G., Sonmez, M., Aydin, M., Yuce, A., Gur, S., Yuksel, M., Aksu, E,H. \& Aksoy, H. 2007. Effects of pomegranate juice consumption on sperm quality, spermatogenic cell density, antioxidant activity and testosterone level in male rats. Clinical Nutrition 27: 289-296.

Yunianto, I., Das, S. \& Mat Noor, M. 2010. Antispermatogenic and antifertility effect of pegaga (Centella asiatica L.) on the testis of male Sprague-Dawley rats. La Clinica Terapeutica 161: 235-239.

Zoha, M.S., Hussain, A.H. \& Choudry, S.A. 1989. Antifertility effects of Andrographis paniculata in mice. Bangladesh Medical Research Council Bulletin 15: 34-37.

School of Biosciences and Biotechnology

Faculty of Science and Technology

Universiti Kebangsaan Malaysia

43600 Bangi, Selangor Darul Ehsan Malaysia

*Corresponding author; email: mahanem@ukm.edu.my

Received: 10 September 2014

Accepted: 8 May 2015 